\title{
BUILDING RESEARCH STATION, GARSTON, WATFORD OPEN DAYS FOR ENGINEERS
}

$\mathrm{T}$ HE purpose of the display of engineering and soil mechanics work of the Building Research Station (Department of Scientific and Industrial Research) at Garston, Watford, during July 15-19, was not so much to give a general account of work in progress as to stimulate the application of the results of research by practising civil and structural engineers. To this end, special emphasis was laid on five lines of research: those concerned with reinforced concrete, steel-framed structures, load-bearing walls, bridges and foundations.

One important contribution to research was mentioned by Sir Ben Lockspeiser, secretary of the Department of Scientific and Industrial Research, in opening the exhibition. Referring to the expert advice and guidance on building research given by the Building Research Board under the chairmanship of Sir Herbert Manzoni, Sir Ben said : "This Board, consisting of people of great ability, achievement and experience in the many and varied aspects of building, give us their time voluntarily and do us a service we could not obtain in any other way. All our D.S.I.R. Stations enjoy this advantage, and it is not generally known how much scientific research owes to the public-spirited men and women who serve on our Boards".

The central theme of the presentation was that the older methods of design lead to under-estimations of the strengths of structures, that more exact methods of design are being made available, and that provision is increasingly being made, in building regulations and codes of practice, for their use.

The safety factors used in structural engineering have to take into account a number of variables, such as the mechanical properties of building materials, quality of workmanship and the knowledge of designers. On the other hand, there are many ameliorative effects, such as rigidity at joints in frames, stiffening by concrete encasing steelwork, stiffening by panel fillings, and 'composite action' generally, that cannot be taken into account until a quantitative assessment of them is possible. Display panels and testing equipment were used to illustrate the Station's work on both aspects of this general design problem.

Research on reinforced concrete has led to the inclusion in the relevant code of practice $(C P$ 114) of recommendations for a new method of design-the load-factor method. The principle behind this method. is that the load that will just cause failure of a structure is sufficiently greater than the working load to bring the probability of failure during the working life below a specified limit. Several exhibits illus. trated research to provide data enabling designers to use the load-factor method of design with safety and economy-research on the control of quality of concrete as well as on the behaviour of walls, beams and other structural components at the point of failure.

With steel-framed buildings, three main lines of investigation are leading to more economic methods of design. Mathematical analysis has been made of a large number of idealized frames with fully rigid joints, to enable the bending moments in the neighbourhood of such joints to be assessed accurately. Secondly, an attack is being made on the problem of what happens in a steel structure when some of the steel is deformed beyond its elastic limit and passes into the plastic range. Formerly, this point was regarded as marking the limit of strength of the structure; in fact, it marks the onset of a redistribution of stresses that may result in a considerable margin of safety before actual collapse occurs. Thirdly, there is the question of how much allowance can be made for the effects of composite action, in a complete building, between the steel frame and floors and panel infillings, and between the steel members and concrete encasements provided primarily for fire protection.

A major difficulty here is that of embodying this more accurate knowledge of structural behaviour in design procedures that are not too complicated for adoption by the profession as a whole. The aim, therefore, is to express the results of mathematical analysis, once their validity has been confirmed by measurement, in simple design charts that can be used with confidence by a designer even though he may not feel at home with the analytical methods that have gone into their preparation.

The thickness of load-bearing walls has in the past been largely determined by rules-of-thumb that have been shown by experience to be safe. Such rules are often wasteful. Examples were shown of work devoted to determinations of the strength of walls under various conditions of loading, so that design recommendations on a calculated-stress basis could be formulated. The results of this work, mainly on walls and piers built with bricks and blocks, largely shaped the recommendations of the code of practice $(C P$ 111) for the design of load-bearing walls-recommendations that can lead to important economies in material.

Research on bridges has naturally been pursued in close liaison with the Ministry of Transport. Perhaps the most important outcome of this work has been, in a sense, an invisible one. Throughout Great Britain there are some thousands of old bridges, carrying traffic much heavier than was envisaged at the time they were built. It was thought that many of these bridges might have to be rebuilt. The Station was asked to investigate, with the view of formulating more accurate ways of assessing the strength of such bridges. From 1936 onwards more than fifty cast-iron girder and masonry arch bridges were tested, some of them being loaded to destruction. Two important conclusions emerged : first, with the girder bridges, a load applied over one girder is partially supported by other girders ; secondly, with both girder and masonry arch bridges, the fill and road-surfacing material gradually becomes consolidated and acts structurally in combination with the girders or arch so as to give a total strength considerably greater than that forecast from consideration of the basic structure alone. Many suspected bridges were thereby reprieved - a matter of immense and immediate importance when, during the Second World War, it became necessary to send heavy military vehicles up and down the country. This work on old bridges alone saved the country many millions of pounds.

Since the War, research on bridges has been con. cerned mainly with modern steel-and-concrete bridge 
decks. The most striking feature of measurements on bridges has been the low values for the strains measured in the girders, even with heavy traffic. Laboratory tests on scale-models have helped to explain this, particularly on the basis of composite action between the girders and the concrete and of the lateral distribution of load among the girders. Several possible new methods of design are being investigated, with the view of gaining all possible advantage from this structural interaction, which previously was ignored.

A working model was used in the exhibition to illustrate a series of tests that measured the dynamic effects of traffic. The impact factor (the ratio of the strain due to a load applied dynamically to that due to the same load applied statically) varied in most cases between $0 \cdot 8$ and $1 \cdot 3$, the commonest values being about unity. In the past, it has been usual to assume an impact factor of $\mathbf{1 . 5}$ or more for design purposes; but the tests show that such a value is unduly high and that a more economical design can be made on the safe basis of an impact factor of 1.25 or even less.

The work on bridges demonstrates in parvo nearly all the principles characterizing the present-day approach to the problems of designing structures above ground. Formerly the approach, in very general terms, was to reduce a structure to the simplest components that could be considered to lead an independent structural existence-joists, girders, columns, walls, slabs; the loading each component could sustain without permanent deformation was then calculated according to simple rules based on tests on such components in isolation ; finally, each component was assumed to be similarly loaded in the complete structure, needing to be strong enough to support the worst probable load distribution. Any component not designed for strength was assumed to make no contribution. Nowadays, the tendency is to consider the behaviour of the complete structure, to measure stresses at critical points in buildings under construction and after completion, to account for these results by more refined theories of stress-strain pattern, and finally to interpret these theories in terms of convenient rules for design. The important thing is that investigation starts with what actually happens in actual structures.

The Building Research Station's work on foundations engineering, since it is carried on chiefly in the field, had to be demonstrated mainly by photographs. Two model-scale investigations were exhibited : in one, a glass-sided tank is used for studying the effect of seepage under hydrostatic pressure at the base of a sheet pile cofferdam; in the other, the effect is examined of proximity between piles in a group on the bearing capacity of each.

Another exhibit included part of the equipment used for measuring pore-water pressures during the construction of earth dams. Pore-water pressure tends to reduce the shear strength of the soil, with a consequent risk of instability as the height of earth fill is increased. Piezometers, incorporating a rigid porous membrane that supports the stresses due to solid material while transmitting hydrostatic pressure, are buried in the dam as work proceeds, permitting direct measurement of pore-water pressures to be made afterwards at a distance. This enables appropriate precautions to be taken if the pore-water pressure threatens to mount too high in relation to the factors contributing to stability.

\section{LAND USE IN BRITAIN}

A CONFERENCE on "Land Use in Britain" was held in the University College of the SouthWest at Exeter during July 15-16. It was organized by the Division for Social and International Relations of Science of the British Association, under the chairmanship of the president of the Division, Mr. P. Ritchie Calder. The Division in this way revived its pre-war function of holding occasional meetings in different parts of the country to discuss problems in which both scientific and social questions are involved. The excellence of the prepared papers and of the discussion, and the success of the conference as a whole, fully justified this initiative.

The theme of the conference was particularly appropriate at a time when most of the local planning authorities in Britain have completed their development plans, as they were charged to do under the Town and Country Planning Act of 1947.

The first speaker was Sir George Pepler, who was chief technical adviser to the Ministry of Town and Country Planning during 1943-46 and planning adviser to the Government of Singapore during 1950-54. His theme was the administrative arrangements necessary to reconcile the demands for land for many different purposes-agriculture, housing, forestry, recreation, military training, roads, airfields, etc. Sir "George emphasized that at present the framing of a national policy of land use is greatly hampered by the number of government departments involved--just as at local government level planning is hampered by the number of local committees. He urged that there should be more co-operation at both central and local government levels. As soon as possible the Minister should summarize statistically the information contained in the first batch of development plans; the summaries should be reviewed and brought up to date every five years, thus producing a periodic 'balance sheet' of the land use of Great Britain.

Mr. Geoffery Clark, planning officer for Devon, then described some of the planning problems of local authorities from his own experience. Above all, he said, it was important to "take the public with you". Plans should not be imposed from above. He had found scale-models particularly helpful in explaining planning schemes to the public.

The second session of the conference considered the need of land for agriculture and forestry. Prof. L. Dudley Stamp, professor of social geography in the University of London, discussing competing uses for land, said that while in the United States there are about thirteen acres of land, including 4-5 acres of productive land, per head of population, in Great Britain there is about 0.8 acre per head, which includes about half an acre of productive farmland. The full use of our present farmland could support a little over half our population. Some 35,000 acres a year of agricultural land would probably be needed for housing, industry and other purposes during the next twenty or so years. Industry must have first priority in an industrial nation, especially as its choice of site was often determined by natural factors such as the location of mineral workings. Housing came next, and here there was considerable controversy as to desirable housing densities. It should not be forgotten that only about a fifth of the agricultural land taken for housing remained potentially productive. Further, the quality of land used should be taken into consideration. If an acre of average 